\title{
Cost-effectiveness of pain management services for chronic low back pain: a systematic review of published studies
}

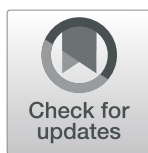

Saja H. AlMazrou ${ }^{1 *}$ DD, Rachel A. Elliott ${ }^{2}$, Roger D. Knaggs ${ }^{3,4}$ and Shiekha S. AlAujan ${ }^{1}$

\begin{abstract}
Background: Chronic low back pain (CLBP) is a highly prevalent condition that has substantial impact on patients, the healthcare system and society. Pain management services (PMS), which aim to address the complex nature of back pain, are recommended in clinical practice guidelines to manage CLBP. Although the effectiveness of such services has been widely investigated in relation to CLBP, the quality of evidence underpinning the use of these services remains moderate. Therefore the aim is to summarize and critically appraise the current evidence for the cost effectiveness of pain management services for managing chronic back pain.
\end{abstract}

Methods: Electronic searches were conducted in MEDLINE, EMBASE and PsycINFO from their inception to February 2019. Full economic evaluations undertaken from any perspective conducted alongside randomized clinical trials (RCTs) or based on decision analysis models were included. Cochrane Back Review Group (CBRG) risk assessment and the Consolidated Health Economic Evaluation Reporting Standards (CHEERS) checklist were used to assess the methodological quality of eligible studies.

Results: Five studies fulfilled eligibility criteria. The interventions varied significantly between studies in terms of the number and types of treatment modalities, intensity and the duration of the program. Interventions were compared with either standard care, which varied according to the country and the setting; or to surgical interventions. Three studies showed that pain management services are cost effective, while two studies showed that these services are not cost effective.

In this review, three out of five studies had a high risk of bias based on the design of the randomised controlled trials (RCTs). In addition, there were limitations in the statistical and sensitivity analyses in the economic evaluations.

Therefore, the results from these studies need to be interpreted with caution.

Conclusion: Pain management services may be cost effective for the management of low back pain. However, this systematic review highlights the variability of evidence supporting pain management services for patients with back pain. This is due to the quality of the published studies and the variability of the setting, interventions, comparators and outcomes.

Keywords: Cost effectiveness, Pain management services, Back pain

\footnotetext{
* Correspondence: Salmazrou@ksu.edu.sa

${ }^{1}$ Clinical pharmacy department, College of Pharmacy, King Saud University,

Riyadh, Saudi Arabia

Full list of author information is available at the end of the article
}

(c) The Author(s). 2020 Open Access This article is licensed under a Creative Commons Attribution 4.0 International License, which permits use, sharing, adaptation, distribution and reproduction in any medium or format, as long as you give appropriate credit to the original author(s) and the source, provide a link to the Creative Commons licence, and indicate if changes were made. The images or other third party material in this article are included in the article's Creative Commons licence, unless indicated otherwise in a credit line to the material. If material is not included in the article's Creative Commons licence and your intended use is not permitted by statutory regulation or exceeds the permitted use, you will need to obtain permission directly from the copyright holder. To view a copy of this licence, visit http://creativecommons.org/licenses/by/4.0/ The Creative Commons Public Domain Dedication waiver (http://creativecommons.org/publicdomain/zero/1.0/) applies to the data made available in this article, unless otherwise stated in a credit line to the data. 


\section{Background}

Low back pain is a common health condition; the estimated global mean point prevalence is $11.9 \%$ [1]. In the United Kingdom (UK), musculoskeletal pain is the leading cause of chronic pain, with low back pain and osteoarthritis together responsible for over half of all cases [2]. According to the Health Survey for England [3], back pain was the second most commonly reported site of pain. Low back pain affects several life domains [4]. Patients with back pain report limitation in daily activities such as work, housework and leisure activities. Low back pain affects relationships, increases feelings of loneliness, cohabitation problems, and concerns surrounding sexual relations, and reduces social interaction. Low back pain has been suggested to be the leading cause of disability worldwide [5], with an associated substantial economic burden. The indirect cost due to productivity loss represent a large proportion of the overall cost; a systematic review of 27 cost-of illness studies conducted worldwide showed that back pain has a major impact on indirect costs, which can represent 50 to $89 \%$ of the total costs [6].

The biopsychosocial model is considered the most valid framework in understanding and managing chronic low back pain (CLBP) [7]. The model addresses pain as a complex and dynamic interaction between physiological, social and psychological elements. In order to manage pain within a biopsychosocial framework a multidisciplinary management approach to address these elements is required [8]. This model requires collaboration between healthcare professionals from different specialties in order to deliver a multidimensional and comprehensive treatment plan.

Combined physical and psychological treatment programs which fulfil the criteria of multidisciplinary pain services have been recommended in clinical practice guidelines, including in the UK, as a rational option for managing people with CLBP $[9,10]$. A recent systematic review of the evidence for the clinical effectiveness of multidisciplinary pain management services on clinically relevant outcomes in CLBP examined 41 randomized controlled trials (RCTs) targeting adults with CLBP for more than 12 weeks [11]. The results demonstrated a moderate effect in favour of the pain management services (PMS) in improving disability and pain.

The cost-effectiveness of pharmacological treatments for CLBP has been assessed by Haas et al. [12]. The systematic review included seven economic evaluations, both modelbased and those carried out alongside RCTs. The results highlighted variable quality of clinical effectiveness data (RCTs), due to sample size not being sufficient to detect differences in outcomes, or convenience sampling being used in non-randomised studies. The quality of some of the economic evaluations was affected by not clarifying the study perspective or omitting to discount future costs or benefits. The results from this review have limited relevance to PMS due to fundamental differences between pharmacological and pain services due to combination of several treatment modalities and their intensity.

Given the increasing prevalence of CLBP [1] and the moderate effect size and perceived high delivery costs of PMS [13], there is a need to critically appraise the costeffectiveness of these services to support stakeholders and decision-makers in the commissioning and reimbursement of PMS. The aim of this systematic review is to summarise and critically appraise the current evidence for the cost effectiveness of PMS in managing CLBP.

\section{Methods}

\section{Types of studies}

Full economic evaluations (i.e. cost effectiveness, cost minimisation, cost-benefit, cost utility and cost consequences analysis), undertaken from any perspective and conducted alongside RCTs or based on decision analysis models, were included.

Partial economic evaluations, published protocols, conference papers and observational studies, such as cohort, case control and non-randomised studies, were excluded.

\section{Types of participants}

Studies including adults (age $>17$ years) who had been referred to PMS from primary care with CLBP were eligible. The Cochrane Back Review Group (CBRG) does not recommend mixing studies about acute and chronic low back pain as the underlying causes differ and, therefore, response to the intervention might be systematically different [14] . Therefore, people with acute or sub-acute low back pain lasting for less than 3 months were excluded. People with low back pain caused by cancer, infection, cauda equina syndrome or inflammatory disorders, such as spondylitis, were excluded, as these types of people require intensive and urgent assessment in secondary care.

\section{Types of interventions}

Although PMS have been recommended in clinical practice guidelines, there is still no consensus around the exact definition of these services [15]. Based on the systematic review by Kamper et al. [11], PMS are defined as health services targeting at least two of the social, physical, psychological and/or occupational aspects provided by one or more healthcare professionals. Given the wide range of terms used to describe these services, we included all relevant terms in our search strategy. The terms including multidisciplinary, interdisciplinary, multimodal, multiprofessional, pain clinics and rehabilitation clinic. An inclusive strategy was adopted in order to identify all relevant publications and then a detailed assessment of the service was undertaken.

PMS based in primary and secondary care were eligible. The components of the services could include pharmacological treatments, physiotherapy, cognitive behavioural 
therapy, complementary medical approaches, such as acupuncture, and other relevant specialties, including rehabilitation medicine, occupational therapy and social services. PMS that offered fewer than two treatment modalities within the service were excluded.

\section{Types of outcome measures}

PMS can aim to either improve functional disability and pain or focus on the vocational outcomes, such as return to work. Therefore, the complex multidimensional aims of these services require the measurement of a variety of outcomes that best address the study aims and research questions. Patient-reported outcomes, such as pain intensity, functional disability, quality of life and return to work, were assessed. Healthcare resource utilisation was also examined.

\section{Search methods for study identification}

Electronic searches were conducted in MEDLINE, EMBASE and PsycINFO from their inception to February 2019. The Health Technology Assessment Database (HTA) in the Centre for Reviews and Dissemination (CRD) were also searched. The NHS Economic Evaluation Database (NHS EED) was searched from inception to February 2016. Reference lists were checked to identify relevant publications.

The search was restricted to studies about humans and published in English. The terms used in the search strategy are listed in Additional file 1 .

\section{Methodological quality assessment}

The Consolidated Health Economic Evaluation Reporting Standards (CHEERS) checklist was used to assess the methodological quality of reporting economic studies [16]. Where the economic evaluation was linked to an RCT, the 12-item checklist recommended by the CBRG was used to assess the RCT's risk of bias [14, 17]. This tool addresses several domains related to a study's internal validity. According to the CBRG guidelines [14, 17], a study is considered to have a "low risk of bias" if at least six domains were categorised as having a low risk of bias. Two reviewers (SA1 \& SA2) screened the titles and abstracts and then one reviewer extracted the data from the eligible studies. A third reviewer (RAE) resolved disagreements if necessary.

The extracted data from each study contained author name, country, year, participant characteristics, intervention, comparator and outcomes. Data allowing assessment of risk of bias and adherence to CHEERS quality criteria were extracted.

\section{Results}

The initial search retrieved 2744 publications. After removing duplicates, and limiting to 'English' and 'human', the results numbered 2019. Of the 2019 results, 1997 studies were judged, via the title and abstract, as not relevant to the scope of this review. The flow chart diagram of the included studies and the reason that studies were excluded is presented in Fig. 1.

The remaining 22 full-text articles were assessed for eligibility. Only five studies fulfilled our inclusion criteria. Seventeen studies were excluded and details of the excluded studies and the reasons for exclusion are described in Additional file 2 .

\section{Study characteristics}

Five studies were included in the review; two studies were conducted in Norway $[18,19]$, two in the Netherlands [20, $21]$ and one in the UK [22]. These studies were published between 2002 and 2014. The characteristics of the included studies are summarised in Table 1 . The total number of participants in the five studies was 1023, with the sample size ranging from 134 to 349 people. Two of the studies only included adults in employment taking sick leave due to CLBP $[19,20]$. The mean age of the participants ranged from 41 to 45.5 years, with equal gender distributions. The mean duration of CLBP symptoms ranged between 5 and 8 years.

A wide range of outcome measures were used in the studies included in this review. Return-to-work (RTW) was the primary outcome in three studies $[19,20,22]$. Four studies used two measures for disability [18, 2022]. Regarding the baseline measures of disease severity, the mean functional disability score using the Roland Morris Disability Score (RMDS) [23] was 14, the score can range between 0 and $24[20,21]$. Whereas the Oswestry Disability Index (ODI) [24] mean score was 43 $[18,22]$, the ODI score ranges between 0 and 100 . The mean pain intensity score from the three studies was 5.8, with the possible ranges of pain intensity being between 0 and $10[18,20,21]$. For all measures, the high scores identify the greatest disability and pain. The mean EQ5D-3 L [25] score ranged from 0.26-0.49 [18, 21, 22]. A generic health status measure, generally, the possible ranges for the EQ-5D-3 $\mathrm{L}$ are between 0 and 1, where high scores mean better health status. A further generic health status measure, the Short Form 6D [26], was also used in conjunction with EQ-5D-3 L in one study [18].

One study looked at costs from the patient and healthcare provider perspectives [22], while the remaining studies were conducted from the societal perspective [18-21]. The length of follow-up was between 12 and 24 months.

The PMS consisted of combinations of cognitive behavioural therapy, physical therapy and workplace interventions. Two studies compared PMS with usual care $[19,20]$, two with surgery $[18,22]$ and one with physical treatment and graded activity (a treatment that includes behavioural and cognitive methods to improve activity 


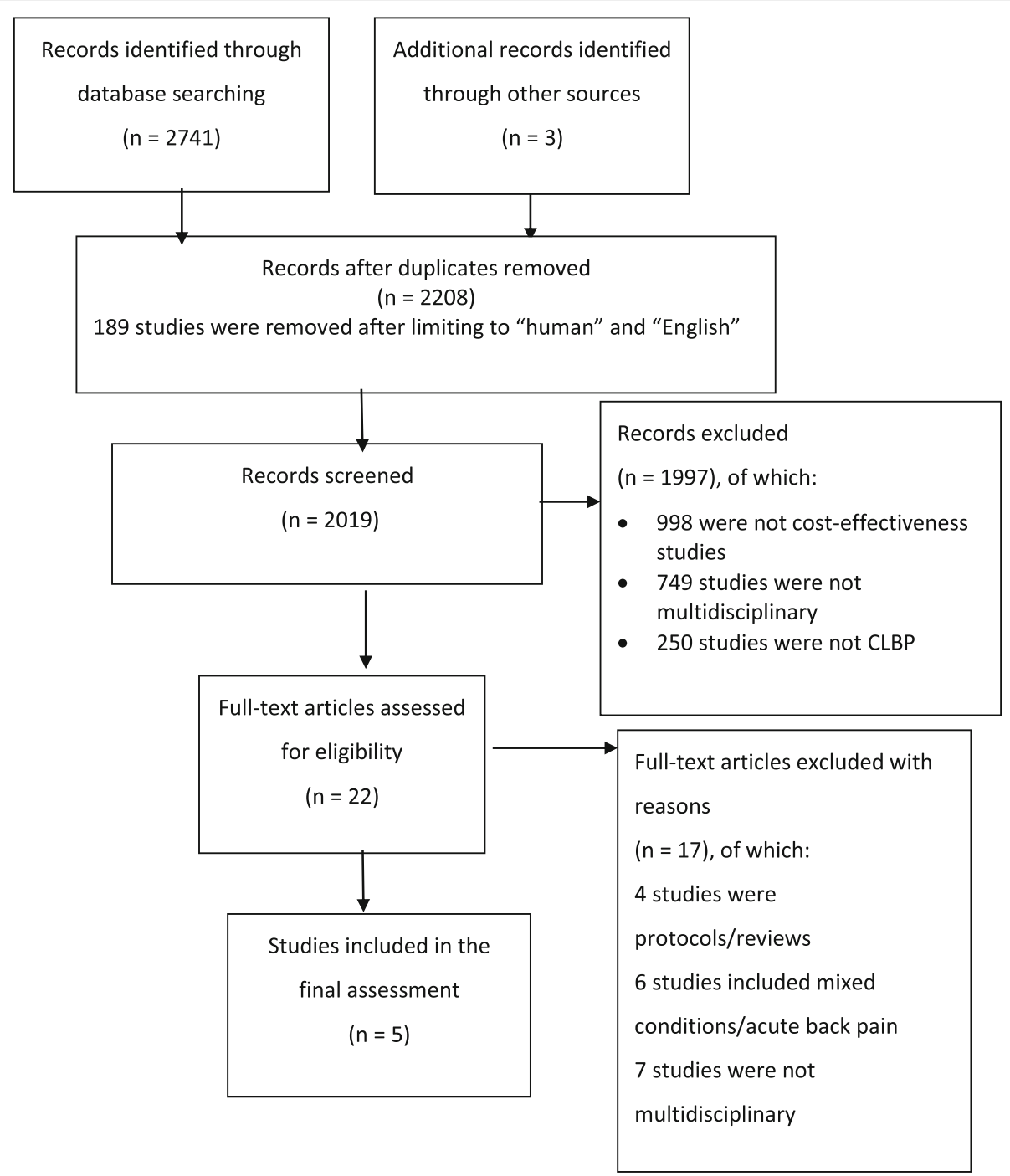

Fig. 1 Flow Chart Diagram

endurance) (two comparators) [21]. The outcomes were return to work $[19,20]$, quality-adjusted life-years (QALYs) using EQ-5D-3 L [18, 21, 22] and disability using RMDQ [21] and ODI [18, 22].

\section{Design and description of pain management services}

The studies were delivered in a secondary care setting only $[18,19,22]$, primary care only [21], or a combined setting [20]. All studies clearly described the service in terms of treatment modalities and the staff involved in delivering these services. However, in some studies the duration of treatment varied between people within the study $[18,20]$. Among the included the duration ranged between one and 3 months and the total number of hours ranged between 3 and $75 \mathrm{~h}$. In another study, the intensity of treatment in terms of the total hours provided was not consistent between individuals in the study [22]. Study participants were generally working-age adults; two studies focused on employees with CLBP $[19,20]$ and no studies included people above 65 years old.

The description of services provided in the included studies is summarised in Table 2.

\section{The comparator}

Two studies, which were conducted in the Netherlands and Norway, compared PMS with "standard care" [19, 20]. In Lambeek et al., standard care consisted of family physician visits, in addition to occupational therapist consultations, provided in a primary care setting [20]. In Skouen et al., standard care consisted of examination in the spine outpatient clinic by a physician, followed by referral back to the GP [19].

Two studies compared the effect of PMS with surgery $[18,22]$. The surgical procedures were total disc replacement [18] and spinal stabilisation [22]. As surgical options 
Table 1 Characteristics of the included studies

\begin{tabular}{|c|c|c|c|c|}
\hline Study ID & Setting & Target population/sample size & Intervention & Comparator(s) \\
\hline $\begin{array}{l}\text { Skouen } 2002 \\
\text { [19] Norway }\end{array}$ & $\begin{array}{l}\text { Outpatient } \\
\text { spine clinic }\end{array}$ & $\begin{array}{l}\text { Patient sick listed for at least } 8 \text { weeks } \\
\text { or employees not on sick leave but } \\
\text { sick listed for at least } 2 \text { months /year } \\
n=195\end{array}$ & $\begin{array}{l}\text { Light multidisciplinary programme (assessment } \\
\text { by physiotherapist and psychologist + individual } \\
\text { education and feedback) } \\
\text { Extensive multidisciplinary programme (4-week } \\
\text { programme - } 6 \text { h session } 5 \text { days/week) consisting } \\
\text { of CBT, education, exercises, work place intervention) }\end{array}$ & Usual care \\
\hline $\begin{array}{l}\text { Rivero-Arias } 2005 \\
\text { [22] United } \\
\text { Kingdom }\end{array}$ & Secondary care & $\begin{array}{l}18-55 \text { years with CLBP }>1 \text { year } \\
n=349\end{array}$ & $\begin{array}{l}\text { Intensive rehabilitation programme (education } \\
+ \text { exercise) led by a physiotherapist and clinical } \\
\text { psychologist }\end{array}$ & $\begin{array}{l}\text { Spinal stabilisation } \\
\text { surgery }\end{array}$ \\
\hline $\begin{array}{l}\text { Smeets } 2009 \\
\text { [21] Netherlands }\end{array}$ & Primary care & $\begin{array}{l}\text { Age between } 18 \text { and } 65 \text { years with } \\
\text { CLBP> } 3 \text { months with RMD score }> \\
3 \\
n=172\end{array}$ & $\begin{array}{l}\text { Active physical treatment }+ \text { graded activity } \\
+ \text { problem training }\end{array}$ & $\begin{array}{l}2 \text { comparators: active } \\
\text { physical treatment } \\
\text { and graded activity } \\
\text { plus problem training }\end{array}$ \\
\hline $\begin{array}{l}\text { Lambeek } 2010 \\
\text { [20] Netherlands }\end{array}$ & $\begin{array}{l}\text { Primary and } \\
\text { secondary care }\end{array}$ & $\begin{array}{l}\text { Adults (18-65) with CLBP in paid } \\
\text { work for at least } 8 \mathrm{~h} / \text { week on } \\
\text { partial sick leave } \\
n=134\end{array}$ & $\begin{array}{l}\text { Integrated care programme (workplace } \\
\text { intervention + graded activity) }\end{array}$ & Usual care \\
\hline $\begin{array}{l}\text { Johnsen } 2014 \\
\text { [18] Norway }\end{array}$ & Hospital & $\begin{array}{l}\text { Adults with CLBP }>1 \text { year with } \\
\text { degenerative change in lumbosacral } \\
\text { intervertebral disc } n=173\end{array}$ & $\begin{array}{l}\text { Multidisciplinary rehabilitation (outpatient } \\
\text { programme focussed on exercise and CBT } \\
\text { delivered by a physiotherapist and physical } \\
\text { medicine specialist) }\end{array}$ & $\begin{array}{l}\text { Total disc } \\
\text { replacement surgery }\end{array}$ \\
\hline
\end{tabular}

CLBP chronic low back pain, CBT cognitive behavioural therapy, RMD Roland Morris Disability

are usually reserved for the severest cases, the patient populations in these studies are likely to be different from those where $\mathrm{GP} /$ medical management is offered as standard care [19-21]. This is demonstrated by the increased pain intensity and lower quality of life at baseline in the surgical studies $[18,22]$.. The mean baseline utility scores (EQ-5D) were 0.26 and 0.49 in studies assessing surgery [18] and nonsurgical treatments [21] as comparators, respectively. Similarly, the baseline pain intensity score was 6.9 in the study assessing surgery [18], while in the study assessing standard care, the baseline score was 5.7 [20]. Therefore outcomes achieved from referral to PMS are not comparable to other studies due to higher baseline pain and disbility levels.

\section{Methodological design}

All of the economic evaluations were conducted alongside RCTs. The risk of bias assessment of the included studies is described in Table 3.

Two of the five studies were considered to have low risk of bias [20, 21]. The major strengths in all of the included studies were that the methods of randomisation and allocation were clear. Moreover, intention-to-treat

Table 2 Service description in the included studies

\begin{tabular}{|c|c|c|c|c|}
\hline Study ID & $\begin{array}{l}\text { Staff delivering } \\
\text { the intervention }\end{array}$ & Intervention description & $\begin{array}{l}\text { Number of hours/day and } \\
\text { duration }\end{array}$ & Notes \\
\hline \multirow[t]{2}{*}{$\begin{array}{l}\text { Skouen } 2002 \\
\text { [19] Norway }\end{array}$} & \multirow[t]{2}{*}{$\begin{array}{l}\text { PT Nurse Psychologist } \\
\text { (if necessary) }\end{array}$} & $\begin{array}{l}\text { Light intervention: Assessment, a } \\
\text { lecture, three individual sessions } \\
\text { and individually-based graded } \\
\text { exercise. }\end{array}$ & $\begin{array}{l}\text { Assessment }(1-2 \mathrm{~h}) \text { Lecture }(1 \mathrm{~h}) \\
\text { Total for individual sessions ( } 45 \\
\text { min) }\end{array}$ & \multirow[t]{2}{*}{$\begin{array}{l}\text { Some people were offered visits } \\
\text { to an external PT, local National } \\
\text { Health Insurance and workplace } \\
\text { visits. }\end{array}$} \\
\hline & & $\begin{array}{l}\text { Extensive intervention: } \\
\text { Educational sessions, exercises } \\
\text { and (occasional) workplace } \\
\text { intervention }\end{array}$ & 6 h, 5 days a week for 4 weeks. & \\
\hline $\begin{array}{l}\text { Rivero-Arias } 2005 \\
\text { [22] United Kingdom }\end{array}$ & $\begin{array}{l}\text { PT and clinical } \\
\text { psychologist }\end{array}$ & $\begin{array}{l}\text { Education Exercises and } \\
\text { hydrotherapy }\end{array}$ & $\begin{array}{l}5 \text { days a week for } 3 \text { weeks The } \\
\text { total hours were } 60-110 \text { ( } 75 \mathrm{~h} \\
\text { on average) }\end{array}$ & $\begin{array}{l}\text { One of the centres did not have } \\
\text { a psychologist or hydrotherapy } \\
\text { sessions. }\end{array}$ \\
\hline $\begin{array}{l}\text { Smeets } 2009 \text { [21] } \\
\text { Netherlands }\end{array}$ & $\begin{array}{l}\text { PT Clinical psychologist } \\
\text { social worker }\end{array}$ & $\begin{array}{l}\text { Physiotherapy Graded activity } \\
\text { with problem-solving training }\end{array}$ & $\begin{array}{l}\text { Physiotherapy: } 105 \text { min three } \\
\text { times a week for } 10 \text { weeks } \\
\text { Graded activity: } 19 \text { sessions } \\
\text { starting from 3rd week. }\end{array}$ & \\
\hline $\begin{array}{l}\text { Lambeek } 2010 \\
\text { [20] Netherlands }\end{array}$ & $\begin{array}{l}\text { OT physician PT OT } \\
\text { medical specialist }\end{array}$ & $\begin{array}{l}\text { Workplace intervention } \\
\text { Graded activity }\end{array}$ & $\begin{array}{l}\text { Graded activity ( } 26 \text { sessions) } \\
\text { for } 3 \text { months or until RTW }\end{array}$ & Coordinated \\
\hline $\begin{array}{l}\text { Johnsen } 2014 \\
\text { [18] Norway }\end{array}$ & $\begin{array}{l}\text { PT Specialist in } \\
\text { physical medicine }\end{array}$ & $\begin{array}{l}\text { Lectures and individual } \\
\text { discussions Daily workout }\end{array}$ & 60 h over $3-5$ weeks & $\begin{array}{l}\text { Nurse, psychologist or social } \\
\text { worker as needed }\end{array}$ \\
\hline
\end{tabular}


Table 3 Risk of bias assessment according to the Cochrane Back Review Group (CBRG)

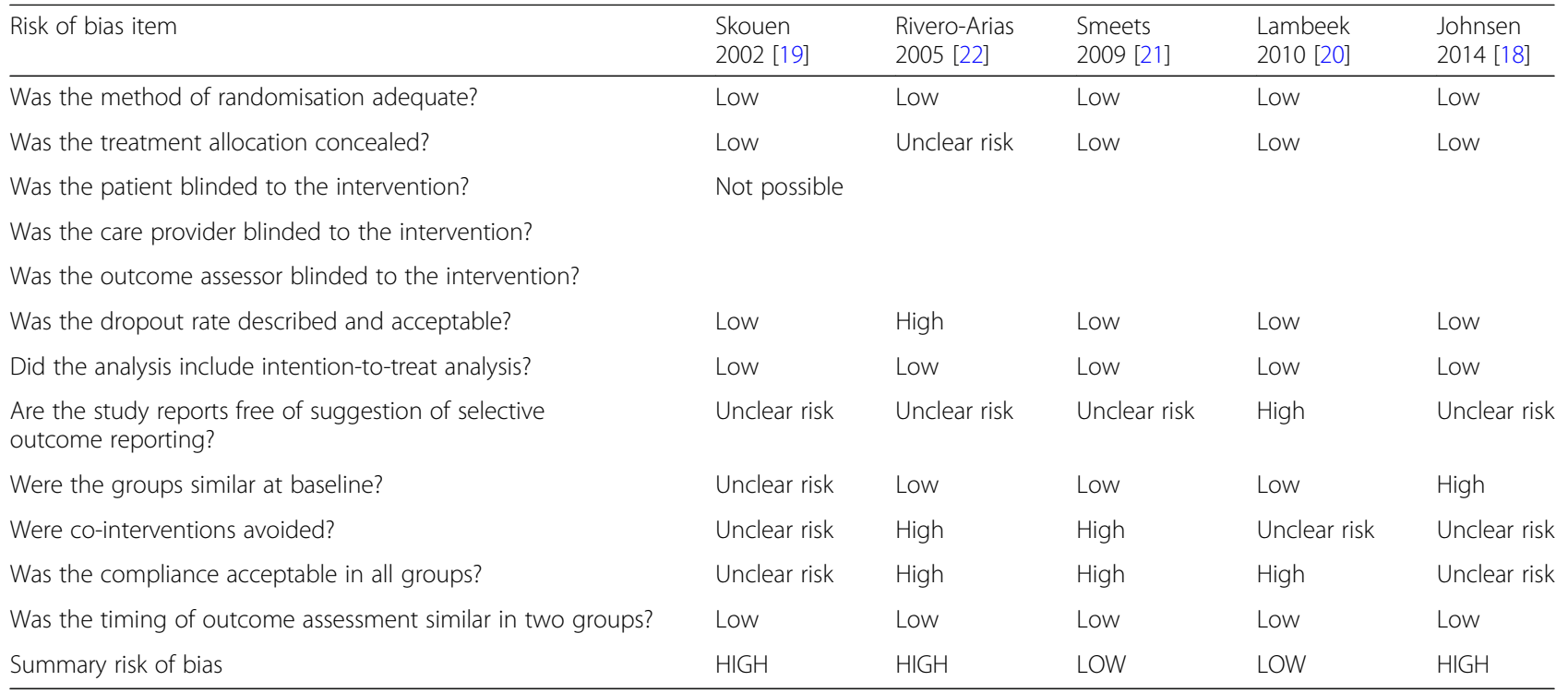

Unclear $=$ item not reported clearly

The study will be considered to have a low risk of bias if 6 or more items are satisfied, otherwise it will be considered to have a high risk of bias

analysis was considered in the statistical analysis for missing data.

High risk of bias was identified in three studies [18, 19, 22]. Two studies reported that the intervention group received extra visits to physiotherapists and other healthcare professionals compared with the standard care arm [21, 22]. Hence, the intervention group might have had better outcomes, compared with standard care, because of these additional visits. One of the important aspects in assessing the quality of RCTs is the sample size and statistical power [27]. Four out of five studies were sufficiently powered (power threshold $80 \%$ ) to detect a difference in functional disability using the ODI [18, 22], RMDS [21] or return to work [20].

Although all included studies incorporated RCTs, randomisation by itself does not ensure that the baseline characteristics of the study participants in the comparator groups are similar [27]. Knowing this information is essential to demonstrate that the participant response to treatment is directly attributed to the intervention effect and not to other patient-related factors. Adjusting effect size for baseline characteristics should be performed using statistical methods, generally regression. In our review, only one study [21] performed regression to adjust effect size for baseline characteristics. Furthermore, two studies clearly reported that there was a significant difference between the study participants at baseline, which they did not then go on to adjust $[18,19]$.

The quality of reporting economic evaluations in terms of costs and outcomes is reported in Table 4, while the details of sensitivity analysis and the results are summarised in Table 5.

\section{Healthcare resource use and cost}

In this review, all of the studies included direct medical and indirect costs. Four studies included direct nonmedical costs, such as travel expenses [18, 20-22]. Four studies took the societal perspective [18-21] and one study took the healthcare provider perspective [22]. Although the last study stated that they conducted their evaluation from a healthcare provider perspective, indirect costs were calculated. Although Skouen et al. stated that their study took a societal perspective [19], direct non-medical costs were not collected.

There are two methods of assessing the service costs, the top-down and the bottom-up (micro-costing) approaches [28]. The top-down approach divides the total budget of a health intervention by the total number of people to give an "average" estimate of cost per patient, whereas the bottom-up approach uses patient-level resource use data to generate costs. The latter is the preferred method in economic evaluations to account for variations in costs between study participants [28]. In this review, three studies used the top-down approach $[18,19,21]$, while two studies used the bottom-up method [20, 22]. The method of collecting costs was implied, rather than clearly stated, in three studies $[19,21,22]$. Only two studies clearly reported all resource use and their unit costs $[20,21]$. In two studies, some unit costs were missing $[18,22]$ and Skouen et al. did not report unit costs [19].

In this review, two studies used postal questionnaires to collect resource use data from people [20,22], which might be subject to recall bias, especially if the recall period is more than 3 months [29]. In Lambeek et al., the recall 
Table 4 Assessment of economic evaluations based on CHEERS criteria (inputs to economic evaluation: costs and outcomes)

\begin{tabular}{|c|c|c|c|c|c|c|}
\hline Study ID & Currency/year & Direct cost & Indirect costs & $\begin{array}{l}\text { Time } \\
\text { horizon }\end{array}$ & Health outcome & $\begin{array}{l}\text { Valuation of } \\
\text { preference outcomes }\end{array}$ \\
\hline $\begin{array}{l}\text { Skouen } \\
2002[19]\end{array}$ & $\begin{array}{l}\text { Norwegian Krone, price of } \\
\text { clinic in 1996, no inflation }\end{array}$ & $\begin{array}{l}\text { Top down } \\
\text { approach }\end{array}$ & Yes & 26 months & Return to work & $\begin{array}{l}\text { NA (utilities were } \\
\text { not collected) }\end{array}$ \\
\hline $\begin{array}{l}\text { Rivero-Arias } \\
2005[22]\end{array}$ & $\begin{array}{l}\text { 2002-2003 GBP inflated to } \\
\text { base year (2005) }\end{array}$ & $\begin{array}{l}\text { Bottom up } \\
\text { approach }\end{array}$ & $\begin{array}{l}\text { Yes. costing total } \\
\text { hours worked by } \\
\text { each patient }\end{array}$ & 24 months & $\begin{array}{l}\text { Return to paid } \\
\text { employment, } \\
\text { total hours worked, } \\
\text { utility using EQ. 5D }\end{array}$ & $\begin{array}{l}\text { Social tariff from } \\
\text { representative sample } \\
\text { of UK population }\end{array}$ \\
\hline $\begin{array}{l}\text { Smeets } \\
2009[21]\end{array}$ & 2003 Euros & $\begin{array}{l}\text { Top-down approach } \\
\text { and costing diaries }\end{array}$ & $\begin{array}{l}\text { Yes, using human } \\
\text { capital approach }\end{array}$ & 12 months & $\begin{array}{l}\text { Disability using } \\
\text { RMDQ,utility using } \\
\text { EQ. 5D }\end{array}$ & $\begin{array}{l}\text { AUC, population and } \\
\text { techniques were not } \\
\text { described }\end{array}$ \\
\hline $\begin{array}{l}\text { Lambeek } \\
2010[20]\end{array}$ & $\begin{array}{l}\text { Index year } 2007 \text { (Euro converted } \\
\text { to GBP) }\end{array}$ & $\begin{array}{l}\text { Bottom up } \\
\text { approach }\end{array}$ & $\begin{array}{l}\text { Yes, using human } \\
\text { capital approach }\end{array}$ & 12 months & $\begin{array}{l}\text { Return to work, } \\
\text { utilities using EQ. } \\
5 D\end{array}$ & $\begin{array}{l}\text { Dutch tariff however no } \\
\text { description of population } \\
\text { or methods used }\end{array}$ \\
\hline $\begin{array}{l}\text { Johnsen } \\
2014[18]\end{array}$ & $\begin{array}{l}\text { Norwegian Krone with } 2006 \text { as a } \\
\text { base year. Costs were adjusted for } \\
\text { inflation into } 2012 \text { prices and } \\
\text { converted to Euros using the } \\
\text { rate } 1 €=6.7 \text { Kr2006 }\end{array}$ & $\begin{array}{l}\text { Top-down approach } \\
\text { and costing diaries }\end{array}$ & $\begin{array}{l}\text { Yes, using human } \\
\text { capital approach }\end{array}$ & 24 months & $\begin{array}{l}\text { Utilities using EQ. } \\
5 \mathrm{D} \text { and SF-6D }\end{array}$ & $\begin{array}{l}\text { QALY was estimated as } \\
\text { AUC using trapezoidal } \\
\text { method. Population and } \\
\text { techniques were not } \\
\text { addressed. }\end{array}$ \\
\hline
\end{tabular}

AUC area under the curve, $C E$ cost effectiveness, $C B$ cost benefit, $C U$ cost utility, QALY quality adjusted life years, EQ. 5D EuroQol 5 dimensions, SF-6D Short Form 6 dimension, GBP British pound, $N A$ not applicable

period was 3 months [20] while, in Rivero-Arias et al., the recall period was 6 months and 1 year [22]. Two studies used costing diaries to collect resource use data [18, 21]. Costing diaries aim to collect data prospectively, which reduces the risk of recall bias. To minimise the risk of incompletion, regular telephone reminders are recommended but neither of the studies using diaries reported providing reminders $[18,21]$.

Productivity loss due to illness can be accounted for by absenteeism, the inability to attend work, and presenteeism, the reduced functionality in terms of quality and quantity while working $[30,31]$. Productivity loss can be measured either objectively, by using attendance records, or subjectively, using self-report by the employee [30]. These methods have some limitations; objective measures might be inaccurate for assessing presenteeism, as they only record employee attendance, with no emphasis on productivity levels in terms of quality.

All studies assessed the effect of PMS on productivity loss. Absenteeism was the only work outcome evaluated. Four studies clearly reported their methods of collecting productivity loss [19-22]. Although the appropriate recall period is still inconclusive, 3 months' recall for absenteeism and 1 week for presenteeism is recommended [30]. Two

Table 5 Economic evaluation based on CHEERS criteria (statistical analysis and results)

\begin{tabular}{|c|c|c|c|c|c|c|c|}
\hline Study ID & Statistical analysis of cost data & $\begin{array}{l}\text { Statistical analysis } \\
\text { for missing data }\end{array}$ & $\begin{array}{l}\text { Incremental economic } \\
\text { analysis reported }\end{array}$ & $\begin{array}{l}\text { Sensitivity } \\
\text { analysis }\end{array}$ & $\begin{array}{l}\text { Difference in } \\
\text { outcome }\end{array}$ & $\begin{array}{l}\text { Difference in } \\
\text { costs }\end{array}$ & $\begin{array}{l}\text { Difference in } \\
\text { outcome and } \\
\text { costs }\end{array}$ \\
\hline $\begin{array}{l}\text { Skouen } 2002 \\
\text { [19] Norway }\end{array}$ & $\begin{array}{l}\text { Not reported, only mean } \\
\text { difference in outcome } \\
\text { evaluated by ANOVA. RR } \\
\text { and } 95 \% \mathrm{Cl} \text { for the effect } \\
\text { of intervention versus } \\
\text { comparator on outcome. }\end{array}$ & Not reported & $\begin{array}{l}\text { productivity gain }=\text { NoK } \\
7,858,100-\text { cost, the net } \\
\text { productivity gain }=240,900\end{array}$ & $\begin{array}{l}\text { Not } \\
\text { performed }\end{array}$ & Yes & $\begin{array}{l}\text { Not } \\
\text { reported }\end{array}$ & No \\
\hline $\begin{array}{l}\text { Rivero-Arias } \\
\text { [22] } 2005 \text { UK }\end{array}$ & $\begin{array}{l}\text { Arithmetic mean for cost } \\
\text { and outcomes }\end{array}$ & $\begin{array}{l}\text { Intention to treat and } \\
\text { multiple imputation } \\
\text { (variance correction) }\end{array}$ & $\begin{array}{l}\text { Bootstrapping (1000 } \\
\text { replications) }\end{array}$ & Yes & No & Yes & Yes \\
\hline $\begin{array}{l}\text { Smeets } 2009 \\
\text { [21] Netherland }\end{array}$ & $\begin{array}{l}\text { student } t \text { test for change in } \\
\text { outcomes, linear regression to } \\
\text { adjust for baseline differences }\end{array}$ & $\begin{array}{l}\text { Intention to treat } \\
\text { analysis, missing data } \\
\text { were replaced by } \\
\text { mean score of cost } \\
\text { and utility }\end{array}$ & $\begin{array}{l}\text { Bootstrapping (1000 } \\
\text { replications) }\end{array}$ & Yes & No & No & No \\
\hline $\begin{array}{l}\text { Lambeek [20] } \\
2010 \text { Netherlands }\end{array}$ & Not reported & $\begin{array}{l}\text { Intention to treat } \\
\text { analysis, multiple } \\
\text { imputation }\end{array}$ & $\begin{array}{l}\text { Bootstrapping (5000 } \\
\text { replications) }\end{array}$ & Yes & Yes & Yes & Yes \\
\hline $\begin{array}{l}\text { Johnsen } 2014 \\
\text { [18] Norway }\end{array}$ & $\begin{array}{l}\text { Student } t \text { test for cost } \\
\text { and utilities }\end{array}$ & $\begin{array}{l}\text { Intention to treat } \\
\text { analysis, multiple } \\
\text { imputation }\end{array}$ & $\begin{array}{l}\text { Bootstrapping }(10,000 \\
\text { replications) }\end{array}$ & Yes & Yes & Yes & Yes \\
\hline
\end{tabular}


studies used "monthly" self-reported methods, utilising calendars [20] and diaries [21]. In another study [22], the employment status was self-reported over a relatively long period of 6 months and 1 year with insufficient information about the measurement method to assess quality. An objective measure was used in one study [19], which utilised the national health insurance registry to assess sickness absence. Johnsen et al. [18] did not report the method of data collection.

In order to value productivity loss among employees, the "human capital approach" and the "friction cost method" can be used [30]. As the friction cost approach can produce lower estimates of cost, it is recommended to use both approaches to determine any methodsdervied difference. Four studies used the human capital approach alone to value productivity loss [18-21]. In Rivero-Arias et al. study the productivity was assessed by calculating the total hours worked by each patient at baseline, six,tweleve and 24 months [22].

\section{Statistical analysis}

The statistical analysis of patient-level cost data needs to be adjusted from standard approaches as cost data are generally "positively skewed", because a small number of people usually require more healthcare resources [28, 32]. Non-parametric tests rely on medians and distributional shape. Non-parametric bootstrapping with replacement is the preferred method to analyse cost data because it compares arithmetic means while avoiding distributional assumptions. Standard parametric tests can be used to analyse cost data only if the sample size is large, where skewness will not affect the validity of the analysis. Barber et al. reported that, for sample sizes larger than 150 participants [33], the t-test is usually robust and valid, as parametric assumptions will generally hold. In this review, two studies used non-parametric bootstrapping to test the difference in cost [20,21], whereas two studies with larger sample sizes, 349 [22] and 173 [18], used parametric t-tests for cost analysis. Skouen et al. did not analyse differences in costs [19].

Discounting is used to estimate the future value of outcomes and costs and assumes present outcomes and costs are considered more valuable than those in the future [28]. Future costs and outcomes should be discounted where follow-up is longer than 1 year, using nationally preferred discount rates. Lack of discounting can lead to inaccuracy in estimating the cost-effectiveness results. In this review, three studies had interventions that continued for 2 years [18, 19, $22]$, two of which reported the discount rate according to the country-specific rates $[19,22]$.

\section{Dealing with uncertainty}

The incremental cost effectiveness ratio (ICER) is the main summary measure of an economic evaluation and is the difference in cost divided by the difference in effect (outcome) between two interventions [28]. The base case analysis generates the ICER from the preferred outcome and cost data. Sensitivity analysis is used to test the sensitivity of the ICER to variation in cost and outcome parameters used in the base case analysis [28, 32]. In one-way sensitivity analysis, one parameter is changed at a time to test the results. Multiple-way analysis changes multiple parameters at the same time. Although one-way sensitivity analysis is easy and understandable, it can underestimate total uncertainty in the ICERs [34].

Probabilistic sensitivity analysis (PSA) assumes that the values of input cost and outcome variables have a probability distribution. Probabilistic incremental economic analysis is usually carried out using bootstrapping to generate credibility intervals that provide a quantitative measure of uncertainty around ICER point estimates ("expected value"). For the graphical representation of ICERs, cost effectiveness planes are used to present the distribution of bootstrapped ICERs [28]. Another common graphical presentation used in economic evaluation is the cost effectiveness acceptability curve (CEAC) [28]. The CEAC is a technique for representing information on uncertainty in cost-effectiveness. A CEAC demonstrates the probability that an intervention is cost-effective compared with the substitute, given the observed data, for a range of maximum monetary thresholds that policy makers are willing to pay for a specific unit change in effect [35].

In this review, all studies carried out one-way sensitivity analysis. Four studies generated ICERs using bootstrapping [18, 20-22] and three of them presented ICERs on cost effectiveness planes [18, 20, 21]. CEACs were used in these studies to present the probability of cost effectiveness [18, 20-22].

\section{Cost-effectiveness of PMS}

The ICERs generated by the studies are summarised in Table 6 . Only one study concluded that PMS dominates usual care (more effective and less costly) [20]. Skouen et al. concluded that multidisciplinary services are costeffective in men only [19]. However, this conclusion needs to be interpreted with caution given that topdown costs were used and there was no sensitivity or statistical analyses reported. Two studies reported that PMS are cheaper and less effective than surgery $[18,22]$. Therefore, a trade-off between cost and effect needs to be considered. Smeets et al. compared PMS with active physical treatment (APT) and graded activity plus problem solving (GAP) [21]. In this study, the PMS was dominated when compared with GAP, while it was cheaper and less effective when compared with APT. 
Table 6 Summary of incremental cost effectiveness analysis results

\begin{tabular}{|c|c|c|c|c|c|c|}
\hline Study ID & Intervention/Comparator & $\begin{array}{l}\text { Outcome } \\
\text { measure }\end{array}$ & $\begin{array}{l}\text { Intervention } \\
\text { cost }\end{array}$ & $\begin{array}{l}\text { Cost } \\
\text { difference }\end{array}$ & Outcome difference & ICER \\
\hline $\begin{array}{l}\text { Skouen } 2002 \\
\text { [19] Norway }\end{array}$ & $\begin{array}{l}\text { Multidisciplinary treatment } \\
\text { vs usual care }\end{array}$ & $\begin{array}{l}\text { Return } \\
\text { to work }\end{array}$ & NoK 9023 & Not reported & $\begin{array}{l}\text { Net productivity gain } \\
\text { NoK } 7,858,100 \text { (USD } \\
924500 \text { ) }\end{array}$ & $\begin{array}{l}\text { Net productivity gain }=\text { NoK } \\
7,240,900 \text { (USD 852000) }\end{array}$ \\
\hline $\begin{array}{l}\text { Rivero-Arias } \\
2005 \text { [22] UK }\end{array}$ & $\begin{array}{l}\text { Intensive rehabilitation } \\
\text { vs surgical stabilisation }\end{array}$ & QALY & $£ 1410$ & - £3304 & -0.068 & $\begin{array}{l}48,588 £ \text { per QALY (CE threshold } \\
\text { 20,000-30,000£ per QALY) }\end{array}$ \\
\hline \multirow[t]{4}{*}{$\begin{array}{l}\text { Smeets } 2009 \\
\text { [21] Netherland }\end{array}$} & \multirow[t]{2}{*}{$\begin{array}{l}\text { Combined treatment vs } \\
\text { active physical treatment }\end{array}$} & RMDS & \multirow[t]{4}{*}{ Not reported } & \multirow[t]{2}{*}{$-€ 456$} & -1.23 & $\begin{array}{l}371 € \text { per one point reduction } \\
\text { in RMDS }\end{array}$ \\
\hline & & QALY & & & 0.014 & $35,060 €$ per QALY \\
\hline & \multirow{2}{*}{$\begin{array}{l}\text { Combined treatment vs } \\
\text { graded activity plus problem } \\
\text { solving }\end{array}$} & RMDS & & \multirow[t]{2}{*}{$€ 4765$} & -1.27 & (dominated) \\
\hline & & QALY & & & -0.045 & (dominated) \\
\hline \multirow[t]{2}{*}{$\begin{array}{l}\text { Lambeek } 2010 \\
\text { [20] Netherlands }\end{array}$} & \multirow[t]{2}{*}{ Integrated care vs usual care } & $\begin{array}{l}\text { Return to } \\
\text { work (days) }\end{array}$ & $£ 1077$ & $\begin{array}{l}£ 217 \text { (direct } \\
\text { cost) }\end{array}$ & -68 & $\begin{array}{l}-3^{\mathrm{a}} £ \text { per } 1 \text { day earlier } \\
\text { return to work }\end{array}$ \\
\hline & & QALY & & $\begin{array}{l}-£ 5310 \\
\text { (total cost) }\end{array}$ & 0.09 & (dominant) \\
\hline \multirow[t]{2}{*}{$\begin{array}{l}\text { Johnsen } 2014 \\
\text { [18] Norway }\end{array}$} & \multirow[t]{2}{*}{$\begin{array}{l}\text { Multidisciplinary rehabilitation } \\
\text { vs total disc replacement }\end{array}$} & $\begin{array}{l}\text { QALY using } \\
\text { EQ-5D }\end{array}$ & $€ 5977$ & - €13,506 & -0.34 & $39748^{\mathrm{a}} €$ per QALY \\
\hline & & $\begin{array}{l}\text { QALY using } \\
\text { SF-6D }\end{array}$ & & & 0.11 & $\begin{array}{l}128,328 € \text { per QALY (CE } \\
\text { threshold } € 74,600 \text { per QALY) }\end{array}$ \\
\hline
\end{tabular}

${ }^{a}$ Cost effective, NoK Norwegian Krone, QALY quality adjusted life years, USD United States Dollar

\section{Discussion}

To our knowledge, this is the first systematic review that summarises the current evidence regarding the costeffectiveness of PMS in CLBP.

This systematic review does not allow conclusive statements about cost effectiveness of PMS to be made for a number of reasons. Firstly, the complex and diverse nature of the interventions, carried out in a range of settings meant that the intervention itself was not a constant. Secondly, the comparators among the included studies varied considerably, affecting realtive costs and effects. Thirdly, patient cohorts in each study were not necessarily comparable across interventions, and, thus, the response to the PMS would also be different. The inclusion criteria in some studies was limited to working adults, which might limit the generalisability of these services to the general population, which include homeworkers, the unemployed and older adults. A trade-off between increasing the generalisibility of studies while limiting the heterogenity by focusing on a specific subset of people with CLBP need to be considered. This could be achieved by using pragmatic RCTs.

In economic evaluation, generalizability is a major issue that need to considered [36]. Several factors may attribute to this limitation including clinical practice patterns, unit costs and healthcare resources use which can be highly varible across different countries and practice settings.

These challenges are augmented by the heterogeneity of back pain, which is as a result of its complex underlying aetiology and clinical course [37] and psychosocial factors that might influence the progression of the condition.
In this review, three studies out of the five have a high risk of bias, due to limitations in RCT methodological design including clear adminstration of co-interventions and variable compliance among groups. Trials of back pain interventions often seem to have methodological limitations leading to a high risk of bias [38]. A Cochrane review of the effectiveness of PMS in CLBP including 41 studies, of which 28 studies were considered to have a high risk of bias [11].

In this review, all economic studies were conducted alongside RCTs and the follow-up period ranged from one to 2 years. Although this length of follow-up gives some idea of the downstream medical cost and outcomes associated with long-term treatment, ideally longer followup (lifetime horizon) is needed. According to the MRC recommendations for complex intervention evaluations [39], a lifetime horizon is needed to demonstrate the sustainability of short term changes in outcomes.

Several shortcomings were found in estimating the cost of the PMS. Using a top-down approach gives the average cost per patient; however, the method is not useful in estimating the cost of people who consume healthcare resources more or less than average patients do, such as people with mild or severe conditions. Unit costs were either poorly reported or not reported at all. In addition methods for assessing indirect costs might be inaccurate as presenteeism doesn't take into account the employee productivity [30].

Apart from methodological limitations in the economic evaluation study design, terminology can be a problem 
when conducting systematic reviews of complex interventions [40]. Service terminology is highly variable across different settings, countries and clinical contexts and this factor might increase the difficulty in searching and identifying relevant publications. Researchers who are interested in conducting systematic reviews in complex interventions need to select either a search strategy that gathers a wide range of heterogeneous studies to inform the literature about factors that influence this heterogeneity and, thus, address these limitations for future research, or use strict search criteria that define the intervention clearly, which can result in a robust conclusion. However, conducting such a review might be difficult when researchers use different terminology. In addition, narrowing the research might result in a small number of studies, given that the type and intensity of treatments provided within PMS are highly variable. The chance of finding studies that have an identical service, in terms of staff, disciplines involved, duration and intensity, is unlikely.

In this systematic review, a broad search criterion was chosen to conduct the systematic review because the main objective was to investigate the cost effectiveness of the PMS regardless of the type or the intensity of the treatments provided. Although it is logical to compare interventions that have the same components to assess cost effectiveness, it is rare to find studies comparing a matching intervention.

Given these challenges, inconclusive results about the cost effectiveness of these services arise from the variability and heterogeneity of the services and the condition respectively, which makes comparison between studies difficult. The other issue is the poor quality of RCTs, which are the source of "effectiveness data" in economic evaluation, leading to weak cost effectiveness results. Finally, the limitations in estimating the cost of services and the short follow-up period affect the results of the economic evaluations.

The economic evaluations identified in this review were alongside RCTs with short follow-up periods, which is insufficient to assess the long term benefit of the service. Decision analysis models, which usually have lifetime cost effectiveness data, were lacking.

\section{Conclusion}

PMS might be cost effective in the management of CLBP. However, this systematic review highlights the discrepancies in the evidence supporting PMS for people with CLBP due to the variability of the setting, interventions, comparators and outcomes. Therefore, more site specfic and better studies are needed. Research directions should focus on optimising the methods of assessing healthcare resource use and cost in order to improve the analysis in the future. In addition, well conducted RCTs with low risk of bias are needed. Finally,assessing the long terms benefits of these services by conducting pragmatic RCTs combined with modelbased economic evaluations is warrented.

\section{Supplementary information}

Supplementary information accompanies this paper at https://doi.org/10. 1186/s12913-020-5013-1.

\section{Additional file 1.}

Additional file 2 .

\section{Abbreviations}

BPI: Brief Pain Inventory; CBRG: Cochrane Back Review Group; CBT: Cognitive behavioural therapy; CEAC: Cost effectiveness acceptability curve; CHEERS: Consolidated Health Economic Evaluation Reporting Standards; CLBP: Chronic low back pain; EQ 5D: EuroQol 5 dimensions; GP: General practitioner/practice; HTA: Health technology assessment; IASP: International Association for the Study of Pain; ICER: Incremental cost effectiveness ratio; IMMPACT: Initiative on Methods, Measurement and Pain Assessment in Clinical Trials; INMB: Incremental net monetary benefit; ISPOR: International Society for Pharmacoeconomics and Outcomes Research; NICE : National Institute for Health and Care Excellence; ODI: Oswestry Disability Index; PMS: Pain management service; QALY: Quality adjusted life years; $\mathrm{RCT}$ : Randomised controlled trials; RMDQ: Roland Morris Disability Questionnaire; SC: Standard care; SMD: Standardised Mean Difference

\section{Acknowledgements}

Not applicable

\section{Authors' contributions}

SA1 undertaking the search, assessing the eligibility od studies and writing the manuscript. SA2 double checking the eligible studies in the title and abstract phase. RE and RK overall revision of the manuscript. All authors agreed the design of the study and approved the final version of the manuscript. SA1" corresponding to Saja Almazrou and SA2 corresponding to Shiekha alaujan

\section{Funding}

The authors extend their appreciation to the Deanship of Scientific Research at King Saud University for funding this work.

\section{Availability of data and materials}

All data generated or analysed during this study are included in this published article and its supplementary information files".

Ethics approval and consent to participate

Not applicable

Consent for publication

Not applicable

\section{Competing interests}

The authors declare that they have no competing interests.

\section{Author details}

${ }^{1}$ Clinical pharmacy department, College of Pharmacy, King Saud University, Riyadh, Saudi Arabia. ${ }^{2}$ Manchester Centre for Health Economics, School of Health Sciences, The University of Manchester, 4th floor, Jean Mcfarlane Building, Oxford Road, Manchester M13 9PL, UK. ${ }^{3}$ Primary Integrated Community Solutions Ltd, Nottingham Business Park, Nottingham NG8 6PY, UK. ${ }^{4}$ Division of Pharmacy Practice \& Policy, The School of Pharmacy, University of Nottingham, University Park, Nottingham NG7 2RD, UK. 
Received: 9 July 2019 Accepted: 20 February 2020

Published online: 12 March 2020

\section{References}

1. Hoy D, Bain C, Williams G, March L, Brooks P, Blyth F, et al. A systematic review of the global prevalence of low back pain. Arthritis Rheum. 2012; 64(6):2028-37.

2. Donaldson L. Chief Medical Offer Annual Report. Chapter: pain: breaking through the barrier; 2008.

3. Bridges S. Health Survey for England: Chapter 9,Chronic Pain; 2011.

4. Froud R, Patterson S, Eldridge S, Seale C, Pincus T, Rajendran D, et al. A systematic review and meta-synthesis of the impact of low back pain on people's lives. BMC Musculoskelet Disord. 2014;15(1):1-14.

5. Buchbinder R, Blyth FM, March LM, Brooks P, Woolf AD, Hoy DG. Placing the global burden of low back pain in context. Best Pract Res Clin Rheumatol. 2013;27(5):575-89.

6. Dagenais S, Caro J, Haldeman S. A systematic review of low back pain cost of illness studies in the United States and internationally. Spine J. 2008;8(1):8-20.

7. Waddell G. The Back Pain Revolution. 2nd ed. London: Churchill Livingstone; 2004.

8. Gatchel RJ, Peng YB, Peters ML, Fuchs PN, Turk DC. The biopsychosocial approach to chronic pain: scientific advances and future directions. Psychol Bull. 2007;133(4):581-624

9. Savigny PKS, Watson $P$, et al. Low back pain: early management of persistent non-specific low back pain. London: National Collaborating Centre for Primary Care and Royal College of General Practitioners; 2009.

10. Chou R, Qaseem A, Snow V, Casey D, Cross JT Jr, Shekelle P, et al. Diagnosis and treatment of low back pain: a joint clinical practice guideline from the American College of Physicians and the American pain society. Ann Intern Med. 2007:147(7):478-91.

11. Kamper SJ, Apeldoorn AT, Chiarotto A, Smeets RJ, Ostelo RW, Guzman J, et al. Multidisciplinary biopsychosocial rehabilitation for chronic low back pain. Cochrane Database Syst Rev. 2014;9:CD000963.

12. Haas M, De Abreu Lourenco R. Pharmacological Management of Chronic Lower Back Pain: a review of cost effectiveness. PharmacoEconomics. 2015; 33(6):561-9

13. Gatchel RJ, Okifuji A. Evidence-based scientific data documenting the treatment and cost-effectiveness of comprehensive pain programs for chronic nonmalignant pain. J Pain. 2006;7(11):779-93.

14. Furlan AD, Malmivaara A, Chou R, Maher CG, Deyo RA, Schoene M, et al. 2015 updated method guideline for systematic reviews in the Cochrane Back and neck group. Spine (Phila Pa 1976). 2015;40(21):1660-73.

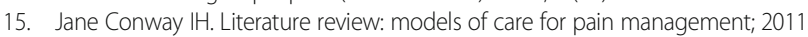

16. Husereau D, Drummond M, Petrou S, Carswell C, Moher D, Greenberg D, et al. Consolidated health economic evaluation reporting standards (CHEERS)--explanation and elaboration: a report of the ISPOR health economic evaluation publication guidelines good reporting practices task force. Value Health. 2013;16(2):231-50

17. Cochrane back and neck forms. http://back.cochrane.org/forms: The Cochrane Back Review Group (CBRG); 2015 [updated Thu 11th Sep 2014.

18. Johnsen LG, Hellum C, Storheim K, Nygaard OP, Brox Jl, Rossvoll I, et al. Cost-effectiveness of total disc replacement versus multidisciplinary rehabilitation in patients with chronic low back pain: a Norwegian multicenter RCT. Spine (Phila Pa 1976). 2014;39(1):23-32.

19. Skouen JS, Grasdal AL, Haldorsen EM, Ursin H. Relative cost-effectiveness of extensive and light multidisciplinary treatment programs versus treatment as usual for patients with chronic low back pain on long-term sick leave: randomized controlled study. Spine. 2002;27(9):901-10.

20. Lambeek LC, Bosmans JE, Van Royen BJ, Van Tulder MW, Van Mechelen W, Anema JR. Effect of integrated care for sick listed patients with chronic low back pain: economic evaluation alongside a randomised controlled trial. BMJ (Clinical research ed). 2010;341:c6414.

21. Smeets RJ, Severens JL, Beelen S, Vlaeyen JW, Knottnerus JA. More is not always better: cost-effectiveness analysis of combined, single behavioral and single physical rehabilitation programs for chronic low back pain. Eur J Pain (London, England). 2009;13(1):71-81.

22. Rivero-Arias O, Campbell H, Gray A, Fairbank J, Frost H, Wilson-MacDonald J. Surgical stabilisation of the spine compared with a programme of intensive rehabilitation for the management of patients with chronic low back pain: cost utility analysis based on a randomised controlled trial. BMJ (Clinical research ed). 2005;330(7502):1239.
23. Roland M, Morris R. A study of the natural history of back pain. Part I: development of a reliable and sensitive measure of disability in low-back pain. Spine. 1983;8(2):141-4.

24. Fairbank JC, Pynsent PB. The Oswestry disability index. Spine (Phila Pa 1976). 2000;25(22):2940-52 discussion 52.

25. EuroQol Group. Eurogol-a new facility for the measurement of health-related quality of life. Health Policy (Amsterdam, Netherlands). 1990;16(3):199-208.

26. Brazier J, Roberts J, Deverill M. The estimation of a preference-based measure of health from the SF-36. J Health Econ. 2002;21(2):271-92.

27. Richards D, Hallberg I. Complex interventions in health: an overview of research methods: Routledge; 2015.

28. Elliott R, Payne K. Essentials of economic evaluation in healthcare: pharmaceutical press; 2005.

29. Mogyorosy ZSP. The main methodological issues in costing health care services: a literature review. York: University of York; 2007.

30. Zhang W, Bansback N, Anis AH. Measuring and valuing productivity loss due to poor health: A critical review. Soc Sci Med (1982). 2011;72(2):185-92.

31. Krol M, Brouwer W, Rutten F. Productivity costs in economic evaluations: past, present, future. PharmacoEconomics. 2013;31(7):537-49.

32. Drummond MF. Methods for the economic evaluation of health care Programmes: Oxford University press; 2005.

33. Barber JA, Thompson SG. Analysis of cost data in randomized trials: an application of the non-parametric bootstrap. Stat Med. 2000;19(23):3219-36

34. Walker D, Fox-Rushby J. Allowing for uncertainty in economic evaluations: qualitative sensitivity analysis. Health Policy Plan. 2001;16(4):435-43.

35. FENWICK E, BYFORD S. A guide to cost-effectiveness acceptability curves. Br J Psychiatry. 2005;187(2):106-8.

36. Drummond M, Manca A, Sculpher M. Increasing the generalizability of economic evaluations: recommendations for the design, analysis, and reporting of studies. Int J Technol Assess Health Care. 2005;21(2):165-71.

37. Fourney DR, Andersson G, Arnold PM, Dettori J, Cahana A, Fehlings MG, et al. Chronic low back pain: a heterogeneous condition with challenges for an evidence-based approach. Spine. 2011;36(21 Suppl):S1-9.

38. Ostelo R, Croft P, van der Weijden T, van Tulder M. Challenges in using evidence to inform your clinical practice in low back pain. Best Pract Res Clin Rheumatol. 2010;24(2):281-9.

39. Moore GF, Audrey S, Barker M, Bond L, Bonell C, Hardeman W, et al. Process evaluation of complex interventions: Medical Research Council guidance. BMJ (Clinical research ed). 2015;350:h1258.

40. Guise JMCC, Viswanathan M, et al. Systematic Reviews of Complex Multicomponent Health Care Interventions. Rockville (MD): Agency for Healthcare Research and Quality (US); 2014.

\section{Publisher's Note}

Springer Nature remains neutral with regard to jurisdictional claims in published maps and institutional affiliations.

Ready to submit your research? Choose BMC and benefit from

- fast, convenient online submission

- thorough peer review by experienced researchers in your field

- rapid publication on acceptance

- support for research data, including large and complex data types

- gold Open Access which fosters wider collaboration and increased citations

- maximum visibility for your research: over $100 \mathrm{M}$ website views per year

At BMC, research is always in progress.

Learn more biomedcentral.com/submission 